\title{
Pengaruh Pemberian Ekstrak Dandang Gendis (Clinacanthus nutans) Terhadap Kadar Glukosa Darah pada Tikus Wistar Model Diabetes Melitus
}

\section{The Effect of Dandang Gendis (Clinacanthus nutans) Extracts on Blood Glucose Levels in Wistar Rats Diabetes Mellitus Model}

\section{Nena Ristra Dewinta ${ }^{1}$, Indri Safitri Mukono ${ }^{2}$, Arifa Mustika ${ }^{3 *}$}

${ }^{1}$ Faculty of Medicine, Universitas Airlangga,

${ }^{2}$ Department of Medicine Biochemistry, Faculty of Medicine, Universitas Airlangga,

${ }^{3}$ Department of Pharmacology and Therapy, Faculty of Medicine, Universitas Airlangga,

Jl. Mayjen. Prof. Dr. Moestopo 47, Surabaya 60132, East Java, Indonesia

*Corresponding author: arifa-m@fk.unair.ac.id

\begin{abstract}
Abstrak
Diabetes Melitus adalah penyakit yang ditandai dengan hiperglikemia karena sekresi insulin yang sedikit, aksi insulin kurang poten, atau disebabkan keduanya. Daun dandang gendis (Clinacanthus nutans) diketahui mengandung antioksidan yang dilaporkan mampu menurunkan kadar glukosa darah. Penelitian ini untuk mengetahui pengaruh pemberian ekstrak daun dandang gendis terhadap kadar glukosa darah pada tikus Wistar model diabetes. Tikus sebanyak 30 ekor yang sesuai kriteria dibagi dalam 5 kelompok yang kemudian diinduksi hiperglikemia menggunakan streptozotocin $50 \mathrm{mg} / \mathrm{kgBB}$. Setelah 2 hari pasca induksi, tikus diberi ekstrak daun dandang gendis sesuai dosis yaitu K1 (75 mg/kgBB), K2 (150 mg/kgBB), dan K3 (300 mg/kgBB) lalu dibandingkan dengan K0 (CMC-Na sebagai kontrol) dan K4 (metformin sebagai obat standar) selama 14 hari. Penurunan kadar glukosa darah yang paling signifikan terjadi pada kelompok K1 dengan pemberian ekstrak dandang gendis $75 \mathrm{mg} / \mathrm{kgBB}$ dibandingkan dengan kelompok $\mathrm{K} 0$, $\mathrm{K} 2$, $\mathrm{K} 3$, dan $\mathrm{K} 4$.
\end{abstract}

Kata kunci: diabetes melitus, hiperglikemia, Clinacanthus nutans

\begin{abstract}
Diabetes Mellitus refers to a disease indicated by hyperglycemia due to abnormality in either insulin secretion or action, or both. Dandang gendis leaves (Clinacanthus nutans) is known to contain antioxidants, which is reported to be able to lower blood glucose levels. The present study aimed to find out the effect of giving the extract of $C$. nutans on the blood glucose of Wistar rat as a diabetic model. Thirty rats that met the criteria were divided into five groups; they were then induced by hyperglycemia using Streptozocin (STZ) 50 $m g / k g$. Two days after the induction, the rats were treated using C. nutans extract with the dosage of K1 (75 $\mathrm{mg} / \mathrm{kgBW}), K 2(150 \mathrm{mg} / \mathrm{kgBW})$, and $\mathrm{K} 3(300 \mathrm{mg} / \mathrm{kgBW})$, then they are compared to KO (CMC-Na as the control) and $K 4$ (metformin as standard medication) for fourteen days. The most significant decrease of blood glucose was found in the group that was treated using $75 \mathrm{mg} / \mathrm{kg}$ of C. nutans extract, compared to the K0, K2, $K 3$, and $K 4$.
\end{abstract}

Key words: Diabetes mellitus, Hyperglycemia, Clinacanthus nutans

Received: 23 November $2019 \quad$ Revised: 1 Desember 2019 Accepted: 13 Desember 2019

\section{PENDAHULUAN}

Diabetes Melitus (DM) merupakan penyakit metabolik yang ditandai dengan hiperglikemia akibat defek dari sekresi insulin, aksi insulin, atau keduanya (American Diabetes Association, 2018). Penyakit ini dikenal sebagai silent killer karena tidak disadari oleh penderita dan diketahui sudah terjadi komplikasi (Infodatin, 2014). Sebanyak 422 juta orang atau $8.5 \%$ dari populasi orang dewasa di dunia dilaporkan menderita diabetes (World Health Organization, 2016). Penderita DM di Indonesia terlapor sebanyak $6.9 \%$ penduduk pada usia $\geq 15$ tahun 
(Litbang, 2013). Prediksi pada tahun 2045, penderita diabetes di Indonesia akan mencapai 16.7 juta orang (14.6-18.2 juta orang) yang merupakan peringkat ke-tujuh terbanyak di dunia (International Diabetes Federation, 2017).

Terapi yang dapat dilakukan pada penderita diabetes yaitu dengan modifikasi gaya hidup dengan pengaturan makanan dan latihan jasmani hingga diperoleh keadaan normoglikemia dengan kadar gula darah puasa $\leq 95 \mathrm{mg} / \mathrm{dl}$ dan 2 jam sesudah makan $\leq 120 \mathrm{mg} / \mathrm{dl}$ ) (Kemenkes RI, 2014). Jika melalui terapi tersebut namun sasaran glukosa tidak mencapai normal, maka diberikan intervensi farmakologis dengan memberikan obat hipoglikemik oral (Direktorat Pengendalian Penyakit Tidak Menular, 2008). Insulin diperlukan oleh pasien dengan ketoasidosis; anak penderita diabetes maupun diabetes melitus tipe 2 jika cara lain gagal mengendalikan DM; gejala-gejala diabetes yang muncul cepat, kehilangan berat badan, kondisi lemah, ketonuria, riwayat keluarga penderita diabetes melitus tipe 1; dan sakit atau akan menjalani operasi; wanita hamil dengan diabetes melitus tipe 2 jika upaya diet ternyata gagal (Badan POM RI, 2014).

Keadaan hiperglikemia persisten meningkatkan produksi spesies oksigen reaktif (ROS) pada sitosol dan mitokondria mendukung deregulasi pertahanan antioksidan yang mampu mengaktifkan beragam jalur metabolik yang memicu munculnya nitro-oxidative stress (NOS) dan stres retikulum endoplasma. Antioksidan merupakan senyawa yang dapat mengurangi atau menunda oksidasi dari molekul dengan menghambat inisiasi atau penyebaran dari rantai reaksi oksidasi (Sifuentes-Franco et. al, 2017).

Dandang gendis (Clinacanthus nutans) berpotensi pada pengobatan herbal tradisional antara lain ruam kulit, gigitan serangga dan ular, lesi akibat virus herpes simplex, diabetes, dan asam urat (Alam et. al., 2016). Ekstrak etanol daun dandang gendis yang merupakan ekstrak terbaik telah teruji mengandung antioksidan seperti flavonoid, saponin, dan tanin dilaporkan memiliki khasiat sebagai antidiabetes (Abdullah dan Kasim, 2017). Flavonoid dapat memodulasi glukosa darah dengan meningkatkan sekresi insulin, mengurangi apoptosis dan meningkatkan proliferasi sel $\beta$ pankreas, mengurangi resistensi insulin, peradangan, stres oksidatif di otot dan meningkatkan translokasi Glucose Transporter Type 4 (GLUT4) (Vinayagam dan $\mathrm{Xu}, 2015$ ). Aksi hipoglikemik saponin melalui peremajaan insulin, pembaruan sinyal insulin, pelepasan insulin dari sel $\beta$, penghambatan aktivitas disakarida, aktivasi sintesis glikogen, penghambatan glukoneogenesis, penghambatan aktivitas $\alpha$-glukosidase, penghambatan ekspresi mRNA glikogen fosforilase dan glukosa 6fosfatase (G-6P) dan meningkatkan ekspresi GLUT4 (El Barky et. al., 2017). Tanin meningkatkan ambilan glukosa melalui aktivasi mediator jalur persinyalan insulin seperti Phosphoinositide 3-Kinase (PI3K) dan MitogenActivated Protein Kinase (p38 MAPK) serta translokasi GLUT-4 (Kumari dan Jain, 2012).

Penggunaan obat tradisional di Indonesia merupakan bagian dari budaya bangsa dan telah dimanfaatkan oleh masyarakat sejak lama (Kotranas, 2007). Meskipun ada obat antidiabetes konvensional, pengobatan diabetes dengan tanaman obat sering berhasil (Kooti et. al., 2016). Terjangkau dan lazimnya sebagian besar obat-obatan tradisional untuk mengatasi penyakit kronis yang tidak menular, membuat obat-obatan tradisional ini semakin banyak diminati (World Health Organization, 2013). Efektifitas dan keamanan obat tradisional perlu didukung hasil penelitian yang memadai (Kotranas, 2007).

\section{METODE PENELITIAN}

Tanaman dandang gendis dalam bentuk bubuk didapatkan dari UPT Materia Medica Batu, Jawa Timur. Bagian tanaman yang diambil adalah daun. Proses ekstraksi dilakukan di Laboratorium Farmakologi FK Unair dengan metode maserasi dengan pelarut polar etanol $70 \%$. Daun dandang gendis dikeringkan selama 72 jam pada suhu kamar dan tidak boleh terkena sinar matahari langsung kemudian dibuat serbuk. Serbuk sampel dibungkus kertas saring kemudian direndam dengan pelarut etanol $70 \%$ dalam bejana tertutup secara bertahap. 
Rendaman tersebut sering diaduk dan dibiarkan selama 24 jam kemudian disaring dengan corong Buchner. Filtrat yang diperoleh diuapkan kandungan etanolnya dengan rotavapor hingga berbentuk pasta. Filtrat dengan bentuk pasta tersebut adalah ekstrak etanol daun dandang gendis.

Prosedur penelitian ini telah dinyatakan laik etik oleh Komisi Etik Penelitian Fakultas Kedokteran Universitas Airlangga dengan No. 146/EC/KEPK/FKUA/2019. Hewan coba yang digunakan adalah tikus jantan (Rattus norvegicus) strain wistar berusia 2-3 bulan dengan rata-rata berat badan 200 gram. Sebelum diberi perlakuan, aklimatisasi dilakukan selama satu minggu untuk penyesuaian lingkungan, mengontrol kesehatan dan berat badan serta menyeragamkan makanannya. Hiperglikemia yang bermakna akan terjadi 2 hari setelah induksi. Kadar glukosa darah dihitung dengan menggunakan glucometer OneTouch ${ }^{\circledR}$ Ultra $^{\circledR}$. Tikus dinyatakan DM jika kadar gula darah $\geq$ $200 \mathrm{mg} / \mathrm{dl}$.

Tikus dikelompokkan menjadi 5 kelompok, yakni (K0) kelompok tikus DM yang hanya memperoleh vehikulum saja (aquadest dan CMC Na 1\%), (K1) kelompok tikus DM yang akan memperoleh ekstrak etanol daun dandang gendis dengan dosis $75 \mathrm{mg} / \mathrm{kgBB}$, (K2) kelompok tikus DM yang akan memperoleh ekstrak etanol daun dandang gendis dengan dosis $150 \mathrm{mg} / \mathrm{kgBB}$, (K3) kelompok tikus DM yang akan memperoleh ekstrak etanol daun dandang gendis dengan dosis $300 \mathrm{mg} / \mathrm{kgBB}$, dan (K4) kelompok tikus DM yang memperoleh metformin $500 \mathrm{mg}$. Ekstrak etanol daun dandang gendis dan metformin diberikan sehari sekali, personde selama 14 hari. Pengambilan darah dan pengukuran kadar glukosa darah tikus dilakukan dengan alat glukometer (kit glukosa enzimatik) pada hari ke-0 sebelum diberi perlakuan dan hari ke-15 setelah diberi perlakuan.

Data hasil kadar glukosa darah diuji normalitas dengan uji Saphiro-Wilk dengan angka normalitas $\mathrm{p}>0.05$. Selanjutnya data diuji dengan One Way ANOVA dilanjutkan dengan uji Bonferroni jika terdapat hasil yang signifikan $p<0.05$. Seluruh uji dilakukan dengan SPSS (IBM, USA).

\section{HASIL DAN PEMBAHASAN}

Rata-rata penurunan glukosa darah terbesar adalah dari kelompok perlakuan $1\left(\mathrm{~K}_{1}\right)$ sebesar $130 \mathrm{mg} / \mathrm{dL}$ dengan pemberian ekstrak dandang gendis dosis $75 \mathrm{mg} / \mathrm{kgBB}$ (Tabel 1).

Berdasarkan hasil penelitian, didapatkan rata-rata kadar glukosa darah yang paling mendekati target terapi adalah pada K1 yang mendapat ekstrak dandang gendis $75 \mathrm{mg} / \mathrm{kgBB}$ atau pada dosis terkecil, sedangkan ekstrak dandang gendis pada dosis $150 \mathrm{mg} / \mathrm{kgBB}$ dan $300 \mathrm{mg} / \mathrm{kgBB}$ berdasarkan penelitian ini tidak dapat menurunkan kadar glukosa darah secara signifikan walaupun pada dosis terbesar menunjukkan penurunan glukosa darah yang lebih besar daripada dosis intermediet (Tabel 1).

Berbeda dengan penelitian yang dilakukan oleh Nurulita et al. (2008) menunjukkan bahwa ekstrak air daun dandang gendis $150 \mathrm{mg} / \mathrm{kgBB}$ dapat menurunkan kadar glukosa darah pada mencit jantan Swiss webster yang diinduksi aloksan, hal ini berarti peningkatan dosis ekstrak dandang gendis pada penelitian ini tidak mampu memberi efek hipoglikemia yang signifikan. Hasil ini sejalan dengan penelitian yang dilakukan oleh Mustika et al. (2017) yang meneliti efek daun Petiveria alliacea terhadap penurunan glukosa darah pada tikus model diabetes pada dosis 90,180 , dan $360 \mathrm{mg} / \mathrm{kgBB}$, memberikan hasil penurunan glukosa darah yang signifikan pada dosis 90 dan $360 \mathrm{mg} / \mathrm{kgBB}$. Obat bahan alam terdapat beberapa komponen senyawa yang saling berinteraksi menimbulkan suatu respon, dengan peningkatan dosis dan semakin banyak jumlah senyawa kimia yang dikandung, maka akan terjadi interaksi yang menyebabkan penurunan efek (Pasaribu, et.al., 2012).

Hasil penelitian ini menunjukkan bahwa peningkatan dosis tidak meningkatkan efek. Terdapat fenomena dapat menjelaskan tidak sejalannya peningkatan dosis terhadap respon farmakologis, yaitu nonmonotonic dose-response relationship (NMDR) (Lagarde et al., 2015). 
Tabel 1. Rata-rata kadar glukosa darah tikus sebelum dan sesudah pemberian ekstrak (mg/dl)

\begin{tabular}{ccc}
\hline Perlakuan & Sebelum & Sesudah \\
\hline $\mathrm{K}_{0}$ & $533.00 \pm 94.79$ & $456.29^{\mathrm{a}} \pm 164.07$ \\
$\mathrm{~K}_{1}$ & $514.75 \pm 84.03$ & $130.00^{\mathrm{b}} \pm 85.94$ \\
$\mathrm{~K}_{2}$ & $509.63 \pm 78.57$ & $476.33^{\mathrm{a}} \pm 151.91$ \\
$\mathrm{~K}_{3}$ & $497.20 \pm 79.44$ & $483.00^{\mathrm{a}} \pm 78.02$ \\
$\mathrm{~K}_{4}$ & $574.67 \pm 43.44$ & $439.17^{\mathrm{a}} \pm 93.73$
\end{tabular}

a,b Superskrip berbeda pada kolom yang sama menunjukkan perbedaan signifikan $(\mathrm{p}<0.05)$

Respon farmakologis pada penelitian ini cenderung menurun pada dosis terendah namun tidak signifikan pada dosis tertinggi. Jika dibandingkan dengan dosis intermediate, penurunan kadar glukosa darah pada dosis tertinggi jauh lebih besar walaupun tidak signifikan. Ada berbagai macam mekanisme dalam NMDR, antara lain sitotoksisitas, reseptor spesifik sel dan jaringan dan kofaktor, selektivitas reseptor, receptor down regulation \& desensitization, persaingan antar reseptor, dan umpan balik negatif endokrin (Lagarde et al., 2015). Belum dapat dijelaksan secara pasti mekanisme mana yang menjelaskan hubungan antara dosis terhadap respon farmakologis pada penelitian ini.

Penurunan kadar glukosa darah pada penelitian ini diakibatkan oleh adanya peningkatan GLUT4 yang terdapat dalam kandungan senyawa antioksidan seperti alkaloid (Agustina, 2011), tanin (Kumari dan Jain, 2012), steroid (Rao dan Gurfinkel, 2000), flavonoid (Vinayagam dan $\mathrm{Xu}, 2015)$, dan saponin (El Barky, et. al., 2017). GLUT4 dianggap sebagai pengatur vital homeostasis glukosa seluruh tubuh karena merupakan satu-satunya transporter yang bertanggung jawab untuk memfasilitasi transportasi glukosa ke sel dalam merespons insulin (Huang dan Czech, 2007).

Stres oksidatif memainkan peran penting dalam progresivitas dan perkembangan diabetes dan komplikasinya (Tiwari, et. al., 2013). Berbagai studi klinis dan model eksperimental menunjukkan saat diabetes melitus, terjadi kerusakan sel yang melibatkan apoptosis dan autofagi sebagai akibat dari stres oksidatif dan pelepasan ROS (Maiese, 2015). Autofagi juga dapat disebabkan karena AGE dari produk glikasi pada diabetes melitus yang menyebabkan komplikasi berbagai organ (Maiese, 2015).

Dalam penelitian yang dilakukan oleh Akbar (2010) senyawa aktif flavonoid terutama flavon ditemukan pada ekstrak etanol $70 \%$ daun dandang gendis. Penelitian yang dilakukan oleh Chelyn, et. al. (2014) menunjukkan bahwa flavon c-glikosida seperti shaftoside, isoorientin, orientin, isovitexin, dan vitexin menjadi mayoritas golongan flavonoid yang ditemukan. Mekanisme utama pada aktivitas antidiabetes flavonoid c-glikosida adalah hambatan pembentukan AGE, $\alpha$-glukosidase, aldose reduktase, dan protein tirosin fosfatase; merangsang penyimpanan glikogen dan aktivasi persinyalan insulin (Xiao, et. al., 2015). Kandungan flavonoid selanjutnya dapat menghambat stres oksidatif yang berpengaruh pada penundaan kerusakan sel di jaringan termasuk sel $\beta$ pancreas (Banjarnahor dan Artanti, 2014).

Aktivitas hipoglikemik ekstrak dandang gendis $75 \mathrm{mg} / \mathrm{kgBB}$ pada penelitian ini jika dibandingkan dengan metformin sebagai obat standar berdasarkan uji post hoc metode Bonferroni menunjukkan adanya perbedaan yang bermakna. Ekstrak dandang gendis pada dosis 150 dan $300 \mathrm{mg} / \mathrm{kgBB}$ tidak didapatkan perbedaan yang bermakna terhadap metformin. Penurunan kadar glukosa darah pada kelompok perlakuan metformin tidak signifikan dapat diakibatkan oleh pemberian metformin bersama makanan berlemak tinggi sehingga mengurangi penyerapan metformin (Sambol, et.al., 1996). 


\section{KESIMPULAN}

Ekstrak daun dandang gendis dosis 75 $\mathrm{mg} / \mathrm{kgBB}$ dapat menurunkan kadar glukosa darah secara signifikan pada tikus galur Wistar model diabetes.

\section{UCAPAN TERIMA KASIH}

Terima kasih pada Universitas Airlangga yang telah mendanai penelitian ini dan seluruh pihak yang terlibat.

\section{DAFTAR PUSTAKA}

Abdullah, N., Kasim, K.F. 2017. In-Vitro Antidiabetic Activity of Clinacanthus nutans Extracts. Int. J. Pharm. Phytochem. Res., 9(6), pp. 846-852.

Agustina, S. 2011. Isolasi Senyawa Golongan Flavonoid Sebagai Antioksidan dari Daun Dandang Gendis (Clinacanthus nutans). [Skripsi]. Fakultas Matematika dan Ilmu Pengetahuan Alam. Institut Pertanian Bogor.

Akbar, H.R. 2010. Isolasi dan identifikasi golongan flavoniod daun dandang gendis (Clinacanthus nutans) berpotensi sebagai antioksidan. [Skripsi]. Fakultas Matematika dan Ilmu Pengetahuan Alam. Institut Pertanian Bogor.

Alam, A., Ferdosh, S., Ghafoor, K., Hakim, A., Juraimi, A.S., Khatib, A., Sarker, Z.I. 2016. Clinacanthus nutans: A review of the medicinal uses, pharmacology and phytochemistry. As. Pacific J. Trop. Med., 9(4), 402-409.

American Diabetes Association. 2018. Standards of Medical Care in Diabetes-2018. Diab. Care, 41(1), 57-5143.

Badan POM RI. 2014. Informatorium Obat Nasional Indonesia (IONI). Jakarta: Pusat Informasi Obat Nasional Badan POM RI.
Banjarnahor, S., Artanti, N. 2014. Antioxidant properties of flavonoids. Med. J. Indones., 23(4), 239-244.

Chelyn, J., Omar, M., Akmal, N., Ranggasamy, R. 2014. Analysis of flavone C -glycosides in the leaves of Clinacanthus nutans (Burm. f.) Lindau by HPTLC and HPLC-UV/DAD. Sci. World J., 2014, 1-6.

Direktorat Pengendalian Penyakit Tidak Menular. 2008. Pedoman Teknis Penemuan dan Tatalaksana penyakit Diabetes Melitus. II penyunt. Jakarta: Direktorat Jenderal Pengendalian Penyakit dan Penyehatan Lingkungan Departemen Kesehatan RI.

El Barky, A. R. Hussein, S.A., Eldeen, A.A.E.A., Hafez, Y.A., Mohamed, T.M. 2017. Saponins and their potential role in diabetes mellitus. Diab. Manag., 7(1), 148158 .

Huang, S., Czech, M.P. 2007. The GLUT4 Glucose Transporter, Cell Metab., 5, 237252.

Infodatin. 2014. Situasi dan Analisis Diabetes, Jakarta: Pusat Data dan Informasi Kementerian Kesehatan RI.

International Diabetes Federation. 2017. IDF Diabetes Atlas - eighth edition, Brussels: International Diabetes Federation.

Kemenkes RI, 2014. Peraturan Menteri Kesehatan Republik Indonesia Nomor 5 Tahun 2014. Jakarta: Kementerian Kesehatan RI.

Kooti, W., Farokhipour, M., Asadzadeh, Z., Larky, D.A., Samani, M.A., 2016. The role of medicinal plants in the treatment of diabetes: a systematic review. Electr. Physic., 8(1), 1832-1842. 
Kotranas, 2007. Kebijakan Obat Trandisional Nasional Tahun 2007. [Online] Available at: http://binfar.depkes.go.id/dat/lama/12063287 90_Buku\%20Kebijakan\%20Obat\%20Tradisi onal\%20Nasional\%20Tahun\%202007.pdf [Accessed 4 August 2019].

Kumari, M., Jain, S. 2012. Tannins: An Antinutrient with Positive Effect to Manage Diabetes. Res. J. Recent Sci., 1(12), 1-8.

Lagarde, F., Beausoleil, C., Belcher, S.M., Belzunces, L.P., Emond, C., Guerbet, M., Rousselle, C. 2015. Non-monotonic doseresponse relationships and endocrine disruptors: a qualitative method of assessment, Environmental Health, 14(1).

Litbang, 2013. Riset Kesehatan Dasar 2013, Jakarta: Badan Penelitian dan Pengembangan Kesehatan Kementerian Kesehatan RI.

Maiese, K. 2015. New Insights for Oxidative Stress and Diabetes Mellitus. Oxidative Medicine and Cellular Longevity, 2015, 117.

Mustika, A., Indrawati, R., Sari, G.M. 2017. Efek Ekstrak Daun Singawalang (Petiveria alliacea) dalam Menurunkan Kadar Glukosa Darah melalui Peningkatan Ekspresi AMPKal pada Tikus Model Diabetes Melitus. J. Farmasi Klinik Indones., 6, 22-31.

Nurulita, Y., Dhanutirto, H., Soemardji, A.A. 2008. Penapisan Aktivitas dan Senyawa Antidiabetes Ekstrak Air Daun Dandang Gendis (Clinacanthus nutans). J. Nat. Indones., 10(2), 98-103.

Pasaribu, F., Sitorus, P., Bahri, S. 2012. Uji Ekstrak Etanol Kulit Buah Manggis (Garcinia mangostana L.) Terhadap
Penurunan Kadar Glukosa Darah. J. Pharm. Pharmacol., 1(1), 1-8.

Rao, A.V., Gurfinkel, D.M. 2000. The Bioactivity of Saponins: Triterpenoid and Steroidal Glycosides. Drug Metab. Drug Interact., 17, 211-235.

Sambol, N.C., Brookes, L.G., Chiang, J., Goodman, A.M., Lin, E.T., Benet, L.Z. 1996. Food Intake and Dosage Level, But not Tablet vs Solution Dosage Form, Affect the Absorption of Metformin $\mathrm{HCl}$ in Man. Br. J. Clin. Pharmacol., 42, 510-512.

Sifuentes-Franco, S., Pacheco-Moises, F.P., Rodriguez-Carrizalez, A.D., Miranda-Diaz, A.G. 2017. The Role of Oxidative Stress, Mitochondrial Function, and Autophagy in Diabetic Polyneuropathy. J. Diab. Res., 2017(1673081), 15.

Tiwari, B., Pandey, K., Abidi, A., Rizvi, S. 2013. Markers of Oxidative Stress during Diabetes Mellitus. J. Biomark., 2013, 1-8.

Vinayagam, R., Xu, B. 2015. Antidiabetic properties of dietary flavonoids: a cellular mechanism review. Nutr. Metab., 12(1), 6079.

World Health Organization, 2013, WHO Traditional Medicine Strategy 2014-2023. Hongkong: World Health Organization.

World Health Organization, 2016. Global Report on Diabetes, France: World Health Organization.

Xiao, J., Capanoglu, E., Jassbi, A., Miron, A. 2015. Advance on the flavonoid c-glycosides and health benefits. Crit. Rev. Food Sci. Nutr., 56(sup1), S29-S45. 